\title{
Legitimációs és hatásköri kérdések az üzemi tanácsokkal és a szakszervezetekkel kapcsolatosan
}

\author{
üzemi megállapodás - kollektív munkajog - kollektív szerződés - \\ üzemi tanács
}

A munka törvénykönyvéröl szóló 2012. évi I. törvény (a továbbiakban: Mt.) több tekintetben is alapvető változást hozott a magyar kollektív munkajog rendszerében. A kollektív szerződések diszpozitív természetének a változása ezek közül az egyik legkiemelkedőbb, hiszen az új törvény kiszélesítette az eltérés lehetőségeit. A korábbi Munka Törvénykönyve (1992. évi XXII. törvény) általános jelleggel a munkavállalóknak kedvező irányban klaudikálóan kógens volt, azaz a kollektív szerződéssel a munkavállalók hátrányára nem lehetett eltérni a törvény szabályaitól. Ehhez képest az új törvény már nem tiltja - ezért egyúttal lehetővé is teszi - a munkavállalókra nézve a törvényben biztosított rendelkezéseknél kedvezötlenebb kollektív szerzödéses rendelkezések elfogadását. A jogszabály miniszteri indoklása kifejtette, hogy a rugalmasabb szabályozással szélesebb körü kollektív autonómiát kívánt biztosítani a munkaerőpiac szereplőinek, annak érdekében, hogy gazdasági, társadalmi és más igényeihez szabadon igazíthassák a foglalkoztatás feltételeit, bizonyos törvényi korlátok mellett. ${ }^{1}$

A kollektív szerződések olyan jogintézményét képezik a munkajognak, amelyben a kötelmi jog szerződéses jellegzetességei, és egyben a kollektív munkajogra általánosságban is jellemzö közjogias jegyek együttesen vannak jelen. A kollektív szerződés, mint szerződés, a szerződést kötő felek, azaz egyrészröl a munkáltató, a munkáltatói érdekképviseleti szervezet, másrészröl a szakszervezet és a szakszervezeti szövetség konszenzusos megállapodása, azonban a munkavállalók tekintetében normatív tartalommal bír, munkaviszonyra vonatkozó szabályként ${ }^{2}$ érvényesül és a normatív tartalmú rendelkezések - legalábbis Magyarországon - valamennyi,

* Dr. Balogh Áron Péter, PhD-hallgató, Debreceni Egyetem Marton Géza Állam- és Jogtudományi Doktori Iskola, arbalogh@gmail.com. A tanulmány az Igazságügyi Minisztérium a jogászképzés színvonalának emelését célzó programjai keretében valósult meg.

A munka törvénykönyvéröl szóló T/4786. számú törvényjavaslat indoklása, Általános Indoklás, 4-16.

2 Az Mt. 13. §-a külön nevesíti azokat a normatív tartalommal bíró megállapodásokat a munkajogban, amelyeknek „kvázi” jogszabályi erőt kölcsönöz: „E törvény alkalmazásában munkaviszonyra vonatkozó szabály a jogszabály, a kollektív szerződés és az üzemi megállapodás, valamint az egyeztető bizottságnak a 293. §-ban foglaltak szerint kötelező határozata." 
a szerződést kötő munkáltatónál munkaviszonyban foglalkoztatott munkavállaló tekintetében kötelező erővel bírnak. . $^{3,4}$

Az Mt. egy másik, és e tanulmány szempontjából külön is kiemelendő újítása, hogy bevezette a normatív hatályú üzemi megállapodásokat. Üzemi megállapodást hagyományosan az üzemi tanács köt a munkáltatóval, amelyben a felek általában csak az egymás közötti viszonyaikat, különösen a részvételi jogok gyakorlásának alapvető szabályait, az együttmüködésük formáját és kereteit konkretizálják, de normatív erővel nem rendelkezik. Kollektív szerződéskötési képességgel nem rendelkező szakszervezet hiányában azonban a törvény lehetővé teszi, hogy a munkáltató és az üzemi tanács üzemi megállapodással munkaviszonyból származó jogokat és kötelezettségeket is szabályozhasson, holott ez hagyományosan a kollektív szerződés, azon belül annak normatív hatályú rendelkezéseinek a rendeltetése.

A jogalkotó célja a normatív üzemi megállapodásoknál is az volt, hogy megkönnyítse és ösztönözze a kollektív megállapodások megkötését üzemi, illetőleg a kisebb munkáltatók szintjén is. ${ }^{5}$ Hagyományosan azonban az üzemi tanács - a szakszervezettel ellentétben - nem konfrontatív, érdekképviseleti feladatokat ellátó szervezet, hanem alapvetően egy semleges, konzultatív szereplője a munkajognak, rendeltetése a munkáltató döntéseiben való részvétel. Többször került már terítékre a magyar jogirodalomban a szakszervezetek és az üzemi tanácsok funkcióinak összemosódása, amely - különösen a normatív üzemi megállapodást alapul véve egyrészről dogmatikai szinten is tetten érhető, másrészről megkérdőjelezi az üzemi tanácsok létjogosultságát, illetőleg szükségességét. Jelen tanulmány célja ezért a szakszervezetek és az üzemi tanácsok szerepének és funkciójának prezentálásán, továbbá más nemzetek szabályozásának bemutatásán túl nemcsak elhatárolni a két intézményt a föbb hatásköri különbségek mentén, hanem egyúttal rávilágítani a magyar szabályozásból eredő legitimációs és funkcionális anomáliákra. Fontos mindenekelőtt azt leszögeznem, hogy itt nem a magyar jogalkotási folyamatok alkotmányjogias, legitimáció-szempontú elemzésével kívánok foglalkozni, hanem azzal, hogy a vizsgált jogintézmények, így a szakszervezet és az üzemi tanács normatív tartalmú aktust hoznak létre, ezért kvázi közhatalmat gyakorolnak. A közhatalomgyakorlásnak pedig központi kérdése, hogy az aktus rendelkezik-e - adott esetben a munkavállalók kifejezett hozzájárulása, felhatalmazása vagy megerősítése révén - demokratikus legitimációval, e körben pedig a kollektív munkajog egyik dilemmája, ki legyen jogosult, továbbá milyen reprezentativitási és egyéb szabályrendszer mentén normatív tartalmú szerződést kötni. ${ }^{6}$

3 KIss György: Munkajog. Osiris, Budapest, 2005, 399 [a továbbiakban: Kıss (2005)].

4 SzABó Imre Szilárd: A kollektív szerződések szerepe a megújult munkajogi szabályozásban. Magyar Munkajog, 2015/1, 1-2.

5 Az Mt. XX. fejezetéhez füzött indoklás szerint: „A törvény több eszköz igénybevételével is erősíteni kívánja a munkajog megállapodáson alapuló jogforrásait. Ennek érdekében - pontosan meghatározott feltételekkel és korlátokkal - lehetővé teszi olyan üzemi megállapodás megkötését, amely a munka dijazására vonatkozó rendelkezések kivételével szabályozzák a munkaviszonyból származó jogokat és kötelességeket."

6 A magyar jogirodalomban a demokratikus legitimáció kérdésével Kiss György már foglalkozott az Alkotmánybíróság Országos Érdekegyeztető Tanáccsal kapcsolatos 124/2008. (X. 14.) számú határozata kapcsán. Tanulmányában azt is kifejtette: „...a demokratikus legitimációhoz a választópolgárok elismerése szüksé- 


\section{A szakszervezetek és az üzemi tanácsok funkciójának bemutatása, különös tekintettel a német (dualista) érdekérvényesítési modellre}

A szakszervezet és az üzemi tanács rendeltetését tekintve - hagyományosan - eltérő jogintézményét képviseli a kollektív munkajognak. A munkavállalók érdekképviseletét, a koalíciós szabadságnak, a munkavállalói részvételi jogok gyakorlásának, leegyszerüsítve, a szakszervezeti és az üzemi tanácsi feladatok és szerepek megoszlásának formáit a munkajogtudományban és a nemzeti szabályozásokban kimunkált érdekérvényesítési modellekkel illusztrálhatom a legegyszerübben, amelynek két fajtáját különböztetjük meg: a monista és a dualista modellt. A monista modell alapján elsősorban a szakszervezetek képviselik a munkavállalókat a munkáltatóval szemben, sőt egyes országok jogában egyenesen kizárt, hogy üzemi tanácsi képviselet és szakszervezet a munkahelyen egyidejüleg létezzen (korábban például Csehországban volt ilyen). ${ }^{7}$ Más monista országokban az üzemi tanácsnak vagy az üzemi szintü képviseletnek bár párhuzamosan helye van a szakszervezet mellett, azonban csekély jelentősége, szerepe van (pl. az Egyesült Királyságban), illetőleg a klasszikus szakszervezeti-érdekképviseleti és az üzemi tanácsi-részvételi jogosítványok összemosódnak, ezért a két szerv hatáskörei nehezen különíthetők el (lásd Olaszországban, Belgiumban). ${ }^{8}$ A dualista modellben (ilyen müködik például Németországban, Hollandiában és Ausztriában) ezzel szemben élesen elkülönülnek egyrészt a koalíciós bázison nyugvó tarifális autonómia, azaz a kollektív szerződéskötés joga, másrészt a munkavállalók védelmi szükségleteinek másik oldalát megjelenítő üzemi alkotmányjog intézményei, általában már jogszabályok szintjén. ${ }^{9} \mathrm{~A}$ dualista modellben olyan struktúra müködik, amelyben a munkavállalók által közvetlenül létrehozott szerv, illetőleg a választott képviselő útján gyakorolt érdekképviseleti funkcióktól elkülönülnek a munkáltató döntésében való részvételi, ún. participációs jogok. E participációs jogokat a szintén választott, és nemcsak a munkáltatótól, de az érdekképviseleti feladatokat gyakorló szervtöl is független testület fogja gyakorolni. Ennek a struktúrának legfőbb célja a munkavállalók konzultációjának és tájékoztatásának üzemi szintű megteremtése, tipikusan üzemi tanácsok útján. ${ }^{10}$

ges, tehát nem elegendő az emberek egy ehhez képest mindenképpen specifikus csoportjának - példának okáért a munkavállalóknak - a felhatalmazása. Ez utóbbi meghatározott szervezetek adott tevékenységénél szintén fontos lehet, például a munkajogban az úgynevezett koalíciók (munkavállalói és munkaadói érdekképviseleti szervek) reprezentativitása szempontjából." Kıss György: A legitimáció hiánya és az „egyetértési jog" természete. Fundamentum, 2009/2, 98.

7 Arany Tóth Marian-Bankó Zoltán-Dux László-Kun Attila-Rúzs MolnÁR Krisztina: Munkajogi kodifikációs megoldások Közép- és Kelet-Európában. Jura, 2005/1, 9; továbbá Fulton, Lionel: Worker representation in Europe. Labour Research Department and European Trade Union Institute, 2015, https://www.worker-participation.eu/National-Industrial-Relations/Countries/Czech-Republic/Workplace-Representation (2018. 07. 10.).

8 ÁsvÁNYI Zsófia: Az Európai üzemi tanács - Részvétel, konzultáció és tájékoztatás az Európai Unió munkajogában. PhD-értekezés, Pécsi Tudományegyetem Állam- és Jogtudományi Kar Doktori Iskola, Pécs, 2015, 58-59.

9 Petrovics Zoltán: A munkavállalók bevonása a munkáltatói döntéshozatali folyamatokba. Pécsi Munkajogi Közlemények, 2016/1, 125.

10 Prugberger így fogalmaz: „Míg ugyanis a dualista modellnél a szakszervezeti és az üzemi tanácsi funkció elkülönül egymástól, addig a monista modellnél a szakszervezetek jelentős szerepet játszanak az üzemi 
A magyar munkajogban szakszervezetnek tekintjük - az Mt. értelmében - a munkavállalók minden olyan szervezetét, amelynek elsődleges célja a munkavállalók munkaviszonnyal kapcsolatos érdekeinek előmozdítása és megvédése. E definíció egyértelműen a szakszervezet tevékenységét emeli ki a szervezeti oldal mellett, és valóban, a szakszervezetek Magyarországon azok az egyesületek, amelyek ezen elsődleges céllal müködnek. Ettől eltérően például a német jogban a szakszervezeteket a koalíciós szabadság alapjoga felöl közelítik meg, ami magában foglalja a munkavállalók szakszervezet-alakítási jogát, sőt a szakszervezetek kollektív szerződéskötési képessége is a koalíciós szabadság gyakorlásából, konkrétan magából a szakszervezet létrehozásából fakad. ${ }^{11}$ Ezzel szemben Nagy-Britanniában, Írországban és Dániában nemcsak a szakszervezetek, hanem egyéb munkavállalói szervezetek is gyakorolhatnak a koalíciós szabadságból folyó jogosultságokat, így köthetnek például kollektív szerződést. ${ }^{12,13}$

A munkavállalók részvétele - tágabb értelemben - számos olyan, különböző mechanizmust felölel, amely során a munkavállalók befolyással bírhatnak a munkáltatói döntésekre, tipikusan üzemi tanácsok útján. ${ }^{14}$ Fontos megemlíteni, hogy az üzemi tanács - a konfrontatív szerepet (is) betöltő szakszervezettel szemben - az együttműködés egyik biztosítéka, és a jogalkotó által meghatározott körben gyakorolja a munkavállalók munkáltatói döntéseket befolyásoló jogosultságait. ${ }^{15} \mathrm{E}$ befolyás általában magában foglalja a munkáltató képviselőjével való konzultációt, a tájékoztatáshoz való jogot, a munkaviszonyra vonatkozó szabályok megtartásának figyelemmel kísérését, és azon kérdésköröket, amelyekben - a törvény kötelező erejü rendelkezése alapján - nem hozható döntés az üzemi tanács hozzájárulása nélkül. Ezt más néven együttdöntési vagy közös döntési jognak nevezzük. Az üzemi tanács klasszikusan a munkáltató és a munkavállalók együttmüködésére, a munkáltató

tanácsi tevékenységben is. Ennélfogva ez utóbbi modellnél üzemi szinten a kollektív szerződés és az üzemi megállapodás azonos." Prugberger szerint továbbá azzal, hogy a német kollektív munkajogi szabályozás elkülöníti egymástól a szakszervezeti koalíciós munkavállalói érdekképviseletet és az üzemi tanácson keresztül történő össz-személyzeti érdekképviseletet, nemcsak kiküszöböli a rivalizálást, hanem a munkamegosztással egyben megsokszorozza, és több csatornássá teszi a munkavállalói (érdek)képviselet erejét. PRUGBERGER Tamás-NÁDAS György: Európai és magyar összehasonlitó munka- és közszolgálati jog. Wolters Kluwer, 2015, 78, 81-83.

11 Grundgesetz (GG), Artikel 3. Absatz 3., továbbá KIss György: A szakszervezetek jogdogmatikai helyzete és jogpolitikai lehetőségei a magyar munkajogi szabályozás alapján 1992-töl napjainkig. In: Kiss György (szerk.): Szakszervezetek és kollektív szerződések az új Munka Törvénykönyvében. Akadémiai Kiadó, Budapest, 2015, 159 [a továbbiakban: Kıss (2015)]; és Kıss György: Alapjogok kolliziója a munkajogban. Justis, Pécs, 2010, 138-139 [a továbbiakban: Kiss (2010)].

12 Trade Union and Labor Relations (Consolidation) Act of 1992, a továbbiakban: TULRCA, Section 5, valamint Section 178 (2)-(3), https://www.legislation.gov.uk/ukpga/1992/52/contents (2018. 03. 31.). Lásd továbbá KovÁcs Erika: A szakszervezetek kollektív szerződéskötési képessége Németországban és Angliában. Jogtudományi Közlöny, 2009/10, 405-406 [a továbbiakban: Kovács (2009)]; Kovács Erika: A szakszervezetek elismerésének összehasonlító elemzése. Jogtudományi Közlöny, 2008/10, 467-470 [a továbbiakban: KoVÁCS (2008)].

13 Brown, Henry Phelps: The Origins of Trade Unions Power. Clarendon Press, Oxford, 1983, 21.

14 Petrovics: i. m., 116-117.

15 BANKó Zoltán-BERKE Gyula-KAJTÁR Edit-Kıss György-Kovács Erika: Kommentár a munka törvénykönyvéhez. Wolters Kluwer, Budapest, 2014, 668. 
döntéseiben való részvételre - participációs jogok gyakorlására - hivatott szerv. ${ }^{16}$ A szakszervezetekhez képest azonban az üzemi tanács egy kevésbé szervezett entitás, ugyanis jogi személyiséggel tipikusan nem rendelkezik, sőt megválasztását, müködésének feltételeit a munkáltató köteles biztosítani, és indokolt költségeit is a munkáltató finanszírozza. ${ }^{17} \mathrm{Ami}$ az üzemi tanács szervezeti függetlenségét illeti, elviekben sem a szakszervezet, sem a munkáltató nem gyakorolhat befolyást a döntéseire. Tagjait és tisztségviselöit a munkavállalók közvetlenül választják a munkáltatónál munkaviszonyban álló munkavállalók közül.

Az üzemi tanácsok kiemelt szerepe vitathatatlanul Németországban az egyik legkiemelkedőbb, ami statisztikailag is igazolható. A 2013-as felmérés szerint az iparosodottabb Nyugat-Németországban a munkavállalók 60 százaléka tartozott kollektív szerződés hatálya alá, amiből mindössze 8 százalék köttetett üzemi/vállalati szinten, és a maradék 52 százalék az ágazati szintủ megállapodás alapján volt foglalkoztatva. A kevésbé iparosodott Kelet-Németországban a kollektív szerződéses lefedettség ${ }^{18}$ mértéke 43 százalék volt, ebből 35 százalék ágazati, és 12 százalék vállalati szinten köttetett. Ezzel összehasonlítva a nyugatnémet munkáltatók 43, a keletnémet munkáltatók 35 százalékánál volt üzemi megállapodás, az 500 főt meghaladó munkavállalót foglalkoztató munkáltatóknál azonban ezt jelentősen meghaladó arányban, nyugaton 87 , keleten 89 százalékánál. ${ }^{19}$ Ezek a számok egyértelműen igazolják, hogy bár a német kollektív szerződéses lefedettségi adatok ágazati szinten magasnak mondhatók, vállalati/üzemi szinten a kollektív szerződések kevésbé érvényesülnek, holott pont az lenne a kollektív autonómia esszenciája, hogy a foglalkoztatás feltételeit - akár vállalati szinten is - a saját, helyi igényeikhez alakíthassák a felek. Az üzemi tanácsok jelenlétük, szélesebb körü és egyértelműen lehatárolt jogosítványaik révén komoly befolyást gyakorolnak a helyi szintú munkáltatói döntésekre, és gyakorlatilag az üzemi megállapodás révén - vállalati szinten - kiegészítik az egyébként Németországban tipikusan ágazati szinten kompetens szakszervezeteket, valamint az ágazati kollektív megállapodásokat.

Az üzemi alkotmányjog egyik fontos rendeltetése, hogy a részvételi jogok gyakorlása révén egyfajta erőegyensúlyt biztosítson a munkáltatói hatáskörök és a szakszervezetek kollektív autonómiája között. Az üzemi tanácsok olyan jogosítványokkal vannak felruházva, amelyekkel jelentős befolyást képesek gyakorolni a munkáltató döntéseire, továbbá az üzemi megállapodással a munkaviszonyt is formálják, azonban csak olyan tartalommal és olyan területeken, amelyet kollektív szerződés nem

${ }^{16}$ „Az üzemi tanácsok fő funkciója a munkavállalói részvétel (betekintés és bizonyos mértékig befolyás) biztosítása a munkáltatói döntéshozatalban, melyen keresztül megvalósulhat a participáció intézménye." In: Szabó Imre Szilárd: Az Üzemi Tanácsok szerepe és szabályozása, http://munkastanacsok.hu/wp-content/ uploads/2015/02/\%C3\%BCt-szaboimre_2015_02.pdf (2016. 03. 22.).

17 Prugberger-Nádas: i. m., 185.

18 Annak mérésére, hogy a kollektív szerződések a munkaerőpiacnak mekkora hányadát szabályozzák, a munkaügyi kapcsolatokkal foglalkozó szakirodalom az úgynevezett kollektív szerződéses lefedettségi rátát alkalmazza. A ráta annak kifejezésére szolgál, hogy a kollektív szerződések hatálya alá eső munkavállalók száma hogyan viszonyul az összes foglalkoztatott számához. Lásd bővebben SoósnÉ CsıKós Szilvia: A kollektív szerződések lefedettségi rátáját meghatározó tényezők. Acta Juridica et Politica, 2004/4, 4.

19 https://www.worker-participation.eu/National-Industrial-Relations/Countries/Germany/Collective-Bargaining (2018. 03. 31.). 
szabályoz, illetőleg oly módon, hogy az nem lehet ellentétes a kollektív szerződéssel. Az üzemi tanács - függetlenül a szakszervezeti tagoktól - a munkajogviszonyban álló munkavállalók által választott szervezet. Tekintettel arra azonban, hogy az üzemi tanácsi tagok 80 százaléka egyben szakszervezeti tag, többen annak az álláspontnak adtak hangot, hogy az üzemi alkotmányjog végeredményben nem más, mint a koalíciós tevékenység szubszidiárius megjelenési formája vállalati szinten. Németországban azonban a szakszervezeteknek a munkahelyeken önálló és átfogó üzemi alkotmányjogi pozíciójuk nincs, az üzemi tanács és a munkaadó együttműködésére semmilyen direkt befolyásuk nem lehet. ${ }^{20} \mathrm{Az}$ üzemi alkotmányjog intézményei ezért egyfajta ellenpólust képeznek a szakszervezeti képviselethez képest. Másfelöl azonban a német jogban az üzemi megállapodások nem terjedhetnek ki olyan kérdésekre, amelyek hagyományosan kollektív szerződés hatáskörébe tartoznak. Tárgya ugyanis csak olyan kérdés lehet, amely egyébként is az üzemi tanács befolyásolási hatáskörébe tartozik, ezáltal nincs „konkurenciaharc” a szakszervezet és az üzemi tanács között sem. ${ }^{21}$

- A német üzemi alkotmányjogi törvény (Betriebsverfassungsgesetz, BetVG) három területet emel ki az üzemi tanács részvételi jogai tekintetében. Az első terület a munkáltató szociális jellegü döntéseiben való részvétel. Ennek keretében az üzemi tanácsot szélesebb körü együttdöntési jog illeti meg, azaz az üzemi tanács hozzájárulása nélkül nem hozható döntés a BetVG által felsorolt tizenhárom, szociális jellegü kérdésben. Ilyen például a munkahely rendjével kapcsolatos szabályok (SZMSZ) megalkotása, a munkarendre, munkaidő kialakítására, bérfizetés helyére, módjára, időpontjára vonatkozó szabályok, a csökkentett napi munkaidő alkalmazása, technológiai eljárások bevezetése és alkalmazása, a munkavállalók teljesítményértékelése, a szabadságolási terv elkészítése, illetve a szabadság kiadásának szabályai, továbbá még néhány, a jogszabályban felsorolt terület. ${ }^{22}$ A részvételi jog gyakorlásának második nagyobb területe a munkáltató személyügyi jellegü döntési köre. E körben a személyügyi terv meghatározásánál a munkáltató tájékoztatni köteles az üzemi tanácsot, az üzemi tanács kezdeményezheti új munkahelyek létesítését, továbbá javaslatot tehet annak jellegére (például részmunkaidő, meghatározott tevékenység), továbbá együttdöntési jog illeti meg a személyügyi kérdőívek kidolgozásában, a képzési tervek elkészítésében, továbbá a képzés és továbbképzés lebonyolításánál együttdöntési jog illeti meg. A befolyásolási jogok harmadik nagy területe a munkáltató gazdasági természetü döntéseinek köre. Gazdasági jellegű területnek minősül különösen: a vállalkozás általános gazdasági és financiális helyzete, a termelési és a költséghelyzet, a termelési és a beruházási program, a racionalizálási tervek, a technológiai és a munkamódszerek, az üzem leállítása vagy termelésének korlátozása, az üzem áthelyezése, a vállalkozás összeolvadása más vállalkozással vagy a szétválás, a vállalkozás szervezetének vagy céljának megváltoztatása, és minden egyéb olyan intézkedés, amely a vállalkozás vagy a munkavállalók helyzetét lényege-

20 KISS (2005): i. m., 424.

21 Petrovics: i. m., 134.

22 A BetVG $\S 87$. 
sen érinti. Gazdasági kérdésekben a törvény - bizonyos munkavállalói létszám felett - kötelező jelleggel írja elő munkavállalókból, üzemi tanácsi tagokból és a munkáltató képviselőiből álló gazdasági bizottság felállítását a hatékonyabb konzultáció és információcsere végett. ${ }^{23}$

\section{A magyar dualista modell jellemzése és föbb dilemmái az 1992-es Munka Törvénykönyvétöl napjainkig}

Az 1992-es Munka Törvénykönyve egy dualista modellt honosított meg, amelyben egyaránt jelen voltak a szakszervezetek és az üzemi tanácsok, jogszabályban körülhatárolt jogosítványokkal. Az új struktúra azonban számos kérdőjelet hagyott maga után. ${ }^{24,25}$ Ezek közül az egyik, hogy a jogszabály a szakszervezetek reprezentativitását és kollektív szerződéskötési képességét az üzemi tanácsi választások eredményéhez kötötte. ${ }^{26}$ Másik példája, hogy a szakszervezet és az üzemi tanács eltérő hatású jogorvoslattal élhetett a munkáltató valós vagy vélt kötelességszegése ellen, amely akár meg is béníthatta a munkáltató döntéshozatali mechanizmusát. ${ }^{27}$ Összességében elmondható, hogy a német koalíciós-tarifális rendszerhez képest az üzemi tanácsok meglehetösen súlytalan és sok esetben értelmezhetetlen szereplőjévé váltak a magyar munkajognak, és a két intézmény szervezeti és funkcionális összemosása feszültség forrása volt. ${ }^{28,29}$

Az Mt. 2012-es újraalkotása során a jogalkotó felismerte a párhuzamos szabályozásból eredő anomáliákat, és egyértelmübbé kívánta tenni a két szervezet közötti elhatárolást. Ezért a szakszervezeti reprezentativitás, valamint a kollektív szerződéskötési képességnek az üzemi tanácsi választásokhoz kötése az új szabályo-

23 BetrVG §§ 74-86, §§ 106-107, továbbá Kıss (2015): i. m., 449.

24 Petrovics ezzel kapcsolatban utal rá, hogy már az 1950-es évektől kezdve felbukkantak az üzemi tanácsok történelmi előzményeinek tekinthető szervek a szakszervezetek mellett, de a szocialista munkajogban megvalósult érdekképviseleti struktúrában jelentős szakszervezeti befolyás érvényesült, melynek eredményeképpen a kollektív munkajog dualista szerkezetéről nem beszélhetünk. PETRovics: i. m., 134.

25 Már az 1992-es Munka Törvénykönyve megalkotása során felmerültek viták azzal kapcsolatosan, milyen szerepet szánjanak az üzemi tanácsoknak. A dualista érdekképviseleti rendszer kialakításával szemben a szakszervezetek fennt kívánták tartani kizárólagos érdekképviseleti szerepüket az üzemi tanácsok „elfoglalásával”, jobb esetben a felettük megvalósuló „gyámkodással”. Lásd bővebben SzaBó Imre Szilárd: Az Üzemi Tanácsok szerepe és szabályozása, http://munkastanacsok.hu/wp-content/uploads/2015/02/\%C3\%BCtszaboimre_2015_02.pdf (2016.03.22.).

26 „A »reprezentativitás« terminológiai problémája kizárólag az 1992-es Munka Törvénykönyve szóhasználata folytán bír jelentőséggel, ugyanis az nem jelentette még önmagában azt, hogy a szakszervezet egyúttal rendelkezik kollektív szerződéskötési képességgel (ún. tarifaképességgel) [...]" In: SzaBó Imre Szilárd: A magyar kollektív munkajog egyes jogértelmezési kérdéseiről. Debreceni Jogi Mühely, 2017/ 3-4 [a továbbiakban: SzABó (2017)], http://www.debrecenijogimuhely.hu/archivum/3_4_2017/a_magyar_kollektiv_munkajog_egyes_jogertelmezesi_kerdeseirol/ (2018. 08. 01.).

27 BANKó-BERKE-KaJTÁR-KISS-Kovács: i. m., 669.

28 Kiss (2005): i. m., 454.

29 Kiss György úgy fogalmaz: „A korábbi Mt. szabályozásának semmi köze nem volt a szakszervezetek koalíciószerü müködéséhez, ráadásul összemosta a koalíciós tarifális, valamint az üzemi alkotmányjogi rendszert." Kıss (2015): i. m., 186. 
zásban már nem szerepelt, és a két szervezet jogköre is egyértelmúsítésre került. Maradtak azonban olyan területek, ahol változatlanul összeütközés tapasztalható a hatáskörök között, továbbá munkavállalói legitimáció-szempontú kérdések is felmerülhetnek.

A törvény a munkajogviszonyra vonatkozó szabályok megtartásának figyelemmel kísérését az üzemi tanácsok általános feladatává teszi. Ezen túlmenően konkrét jogosultságokat is nevesít, amelyeket a gyakorolható részvételi jog terjedelmének mértéke szerint három csoportba sorolhatunk. Az üzemi tanács egyik legfontosabb joga az Mt. 262. § (2) bekezdésében foglaltak szerint a tájékoztatás kérése, valamint tárgyalás kezdeményezése. Ami a tájékoztatás jogát jelenti, az gyakorlatilag kiterjed minden olyan tényállásra, amely a munkajogviszonyra vonatkozó szabályok érvényesülését érinti, és az üzemi tanácsnak joga van ugyanebben a körben az ok megjelölésével tárgyalást kezdeményezni, amelyet a munkáltató nem utasíthat vissza (e szabály kikényszeríthetősége azonban egy komoly dilemma a gyakorlatban). ${ }^{30}$ A tájékoztatási jog tekintetében az Mt. külön nevesíti, hogy a munkáltató félévente köteles tájékoztatni az üzemi tanácsot a gazdasági helyzetét érintő alapvető kérdésekről, a munkabérek változásáról, a bérkifizetéssel összefüggő likviditásról, a foglalkoztatás jellemzőiről, a munkaidő felhasználásáról, a munkafeltételek jellemzőiről, a munkáltatónál foglalkoztatott munkavállalók számáról és munkakörük megnevezéséről. Ez a tájékoztatás szoros kapcsolatba hozható az üzemi tanács általános, jogszabályok megtartását figyelemmel kísérő funkciójával is.

Az üzemi tanács másik fontos jogosultsága a konzultációs joga. Általános szabályként a munkáltató a munkavállalók nagyobb csoportját érintő munkáltatói intézkedésekkel és szabályzatokkal kapcsolatos döntése előtt legalább tizenöt nappal kikéri az üzemi tanács véleményét. $E$ jogosultság speciális formájának tekinthető az üzemi tanácsnak a csoportos létszámcsökkentésnél, és az azt megelőző döntésnél gyakorolt konzultatív szerepe is. Az Mt. a konzultáció terjedelmét is meghatározza, amit megállapodás érdekében, a kezdeményezésben megjelölt célnak megfelelően oly módon kell lefolytatni, hogy biztosított legyen a felek megfelelő képviselete, a közvetlen, személyes véleménycsere és az érdemi tárgyalás. A konzultációhoz döntést felfüggesztő hatály is kapcsolódik, hiszen a folyamatban lévő konzultáció tartama alatt - hosszabb határidőt tartalmazó eltérő megállapodás hiányában - legfeljebb a kezdeményezés időpontjától számított hét napig a munkáltató a tervezett intézkedését nem hajthatja végre. Megállapodás hiányában a munkáltató a határidő lejártakor a konzultációt befejezheti. ${ }^{31}$

Az üzemi tanácsok harmadik jogosítványa a magyar munkajogban az együttdöntés, ami egyetlen nevesített területen érvényesül, méghozzá a jóléti célú pénzeszközök felhasználása tekintetében. A korábbi szabályozás szerint az üzemi tanácsot együttdöntési jog illette meg a jóléti célú ingatlanok hasznosítása tekintetében is, de

30 Az Mt. a gyakorlatban esetlegesen felmerülő viták megelőzése érdekében a tájékoztatást is definiálta a 233. $\S$ (1) bekezdésének a) pontjában, amely szerint tájékoztatás: a munkaügyi kapcsolatokkal vagy a munkaviszonnyal összefüggő, törvényben meghatározott információ átadása, ennek megismerését, megvizsgálását és az ezzel kapcsolatos vélemény kialakítását és képviseletét lehetővé tévő módon.

31 BANKó-BeRKE-KAJTÁR-KIsS-KovÁcs: i. m., 689-693. 
az új szabályozásban ez is szükítésre került. Amennyiben a felek között nincs egyetértés, a vitában az Mt. 293. § (2) bekezdése alapján döntöbíró dönt. ${ }^{32}$

Általánosságban elmondható, hogy a magyar üzemi tanácsoknak a német (dualista) modellhez képest lényegesen szükebb területen van lehetőségük a munkáltató döntésének befolyásolására, egyes területeken pedig a jogosultság terjedelme korántsem magától értetődő. Nem egyértelmű például, hogy konzultációs jog tekintetében mit tekinthetünk munkavállalók nagyobb csoportját érintő intézkedésnek, azt adott esetben a teljes foglalkoztatotti létszám vagy az érintettek száma alapján kell-e meghatározni? Megjegyzendő továbbá, hogy a jelenlegi szabályozásban biztosított, különösen a német üzemi alkotmányjogi rendszerhez képest szűkebb körű együttdöntési jogosítványokkal felruházott üzemi tanácsoknak a munkáltatói döntésekben való részvételéről túlzás lenne beszélni, hiszen az gyakorlatilag egyetlen, nem túl kardinális területen megkerülhetetlen, és a jogosultságok áttekintését követően egyértelműen súlytalan, jóindulattal is csak egy konzultatív jellegủ szervet takar.

\section{A kollektív szerződések jogi természete}

A kollektív szerződés, ahogy fentebb már utaltam rá, a koalíciós szabadság gyakorlásának kézzel fogható produktuma, így egyértelmúen - különösen a dualista érdekérvényesítési modellre figyelemmel - a szakszervezetekhez köthető jogintézmény. Fontos jellemzője kettős természete, ugyanis, mint szerződés, a szerződést kötő felek (a munkáltató, a munkáltatói érdekképviseletek, valamint a szakszervezet és a szakszervezeti szövetség) önrendelkezésén nyugvó jogi aktus, azonban a munkaviszonyok tartalmát átalakitó ereje és kiterjesztő hatálya (például az újonnan „belépő” munkavállalók tekintetében) a normatív természetét igazolja. ${ }^{33}$ Német dogmatikai alapokon nyugodva ezért a magyar munkajogtudományban is elkülönítik a kollektív szerződés normatív és kötelmi rendelkezéseit. ${ }^{34} \mathrm{~A}$ kötelmi hatályú rendelkezések a szerződést kötő felek, így a munkáltató és a szakszervezet egymás közötti viszonyát, a szerződés megkötésével, teljesítésével, megszüntetésével, jogaik gyakorlásával, kötelezettségeik teljesítésével kapcsolatos magatartását szabályozzák. E rendelkezések szerződéses jellegükből fakadóan csak a felek részére határoznak meg jogokat és kötelezettségeket. A normatív hatályú rendelkezés azonban valamennyi, a kollektív szerződés hatálya alá tartozó munkavállalónak a munkaviszonyból származó vagy az ezzel kapcsolatos jogait vagy kötelezettségeit szabályozza. A normatív rendelkezéseken nyugszik a kollektív szerződések valódi normatív tartalma, hiszen munkaviszonyra vonatkozó szabályként, jogszabályhoz hasonló erővel

32 Az új törvény szükítette az egyébként is súlytalan területeken érvényesülő együttdöntési jogot, amely a korábbi, 1992-es Mt.-ben kiterjedt a jóléti célú ingatlanok hasznosítására is. A 2012-es Mt. megalkotását megelőzően Prugberger Tamás éppen amellett foglalt állást, hogy e jogosítványt erősíteni kellene. Lásd Prugberger Tamás: Az országos, az ágazati és a területi érdekegyeztetés, valamint az üzemi tanács jövője és jogi szabályozásuk megreformálásának kérdései. Magyar Jog, 2012/1, 28-35.

33 Kıss (2015) i. m., 78.

34 KovÁcs Rita: A kollektív szerződések szerepe a magyar munkajogban. In: Székely Tünde (szerk.): XII. RODOSZ Konferenciakötet. Editura Marineasa, Kolozsvár, 2011, 21. 
érvényesül azon munkavállalók munkaviszonyában is, akik közvetett módon - így pl. nem voltak tagjai a kollektív szerződést kötő szakszervezetnek - sem vettek részt a kollektív szerződés megkötésében. ${ }^{35}$

A kollektív akarat, illetve a munkavállalói közösség/kollektíva egységének elve nyilvánul meg abban a szabályozási technikában, amelynek értelmében a kollektív szerződés hatálya kiterjed mindazon munkavállalókra, akik azoknál a munkaadóknál állnak alkalmazásban, amelyekre a kollektív szerződés hatálya egyébként kiterjed. ${ }^{36}$ A kollektív szerződés ugyanis egyes országokban - így például Magyarországon, Németországban - külön, egyéni megállapodás nélkül is beépül a kollektív szerzödést kötő munkáltatónál foglalkoztatott valamennyi munkavállaló munkaviszonyába. Emiatt azonban egy olyan sajátos értelmet is nyer a kollektív autonómia a munkavállalók szempontjából, hogy a rendeltetésének megfelelő gyakorlásához egyben egy egyensúlyi állapot fenntartása is szükséges a kollektív szerződést kötő, illetőleg kollektív tárgyalásokat folytató szereplőktől, abból adódóan, hogy a szakszervezet a tevékenységétöl tartózkodó, nem tag munkavállalókat is képviseli. ${ }^{37}$ Azaz olyan érdekképviseleti szervekre van szükség, amelyek nemcsak megfelelő legitimációval és támogatással rendelkeznek a munkavállalók közössége felöl, hanem egyben képesnek is kell, hogy legyenek arra, hogy a kollektív autonómia gyakorlása útján a képviselt érdekeknek megfelelően alakítsák valamennyi munkaviszony tartalmát. A kollektív szerződéssel - mindezt általában a szakszervezet útján - gyakorolják a munkavállalók a koalíciós szabadságból fakadó tarifális autonómiájukat, és ezáltal lehetőség nyílik arra, hogy a munkáltatóval közösen alakítsák társadalmi, szociális, gazdasági és egyéb igényeikhez a foglalkoztatási feltételeket. Erre figyelemmel a koalíciós szabadságból fakadó tarifális autonómia egyértelműen a szakszervezetekhez, munkavállalói érdekképviseletekhez köthető jogosultság. A kollektív szerződés pedig egyben annak a kézzelfogható bizonyítéka, hogy milyen mértékủ az erőegyensúly, illetőleg annak eltolódása a szerződést kötő munkáltató és szakszervezet között, továbbá, hogy a szakszervezet a munkavállalói igényeknek - érdekképviseleti tevékenysége révén - milyen mértékben tudott érvényt szerezni.

\section{Az üzemi alkotmányjog, az üzemi megállapodások rendeltetése és a normatív üzemi megállapodással kapcsolatos anomáliák}

Az üzemi megállapodások jelentőségének vizsgálatához, valamint a magyar szabályozással kapcsolatos anomáliák bemutatásához, úgy gondolom, szükséges külön rávilágítanom a magyar jogalkotás mintájául szolgáló német üzemi alkotmányjog, a szakszervezetek és üzemi tanácsok viszonyát jellemző német dualista modell, továbbá a német jog szerinti kollektív szerződések és az üzemi megállapodások közötti összefüggésekre. Németországban valamennyi szakszervezet rendelkezik kollektív szerződéskötési, más néven tarifális képességgel (Tariffähigkeit), amely

35 BeRKE Gyula: A kollektív szerződés a magyar munkajogban. Utilitates, Pécs, 2014, 148.

36 KIss (2015): i. m., 164.

37 KIss (2015): i. m., 161-162. 
már alapításuktól kezdődően megilleti őket. Annak érdekében azonban, hogy a szakszervezetek megfelelő legitimitással rendelkezzenek az (üzemi szintű) kollektív megállapodás megkötésére, a tarifális képesség kiegészült a német szövetségi munkaügyi bíróságok által kimunkált követelménnyel, a magyar szakirodalomban szociális cselekvőképességnek nevezett Soziale Machtigkeittal. ${ }^{38}$ Annak érdekében tehát, hogy a megfelelő támogatottsággal, vagyonnal, legitimációs bázissal nem rendelkező szakszervezetek ne köthessenek kollektív megállapodásokat, a német bíróságok vizsgálják, hogy a szakszervezet rendelkezik-e a tagjainak megfelelő érdekképviselethez szükséges feltételekkel. Azok a tényezők, amelyek e feltételnek való megfelelést igazolják, többek között a szakszervezet taglétszáma, munkáltatótól, államtól, pártoktól és egyéb szervezetektöl való függetlensége és a financiális helyzete. ${ }^{39,40}$

Ami a magyar szabályozást illeti, korábban már utaltam rá, hogy a jogalkotó nem titkolt szándéka volt a kollektív autonómia kiszélesítése, ösztönözve ezáltal a kollektív szerződések megkötését ágazati és vállalati szinten egyaránt. A szakszervezetek kollektív szerződéskötési képessége korábban - ahogy azt fentebb már bemutattam - az üzemi tanácsi választások eredményéhez volt kötve. Az új szabályozással azonban e két jogintézményt is szétválasztották, és jelenleg kollektív szerződést köthet az a szakszervezet, amelynek a munkáltatónál munkaviszonyban álló tagjainak száma eléri a munkáltatónál foglalkoztatott munkavállalók tíz százalékát. Amennyiben több szakszervezet is rendelkezik képviselettel, azok a szakszervezetek köthetnek közösen kollektív szerződést, amelyek megfelelnek a tízszázalékos előfeltételnek, azaz koalíciós kényszer érvényesül.

A jelenlegi magyar szabályozás - ahogy azt már a bevezetőben bemutattam - lehetővé teszi, hogy szerződéskötési képességgel rendelkező szakszervezet hiányában gyakorlatilag az üzemi tanács kössön kollektív megállapodást vállalati/üzemi szinten. E megoldás eredményeként azonban nem túlzás kijelenteni, hogy a munkáltatók, különösen a kis- és középvállalkozások, sőt bizonyos esetben a munkavállalók, de facto nem feltétlenül érdekeltek abban, hogy üzemi szinten szakszervezet legyen jelen a munkáltatónál, illetőleg, hogy az kollektív szerződést kössön. Ennek egyik oka, hogy a kívánt rugalmas, vállalati feltételekhez igazodó szabályozás üzemi megállapodással is elérhető. Másik része talán az, hogy a szervezeti keretek fenntartásával tagdíjakkal járó adminisztráció is elkerülhető. Tekintettel arra, hogy az üzemi megállapodásban a felek kizárólag a munka dijazására vonatkozó XII. fejezettől (alapbér számítása, bérpótlékokra, távolléti díjra vonatkozó szabályok) nem térhetnek el, ez a lehetőség a munkavállalók számára egy hátrányosabb lehetőség, de az üzemi tanács számára egy erős jogosítvány a tekintetben, hogy beleszólhasson a foglalkoztatási feltételekbe. ${ }^{41}$

38 KISs (2015): i. m., 167, továbbá részletesebben HEMmEN, Wolfgang: Durchsetzungsfähigkeit als Kriterium für den Gewerkschaftsbegriff im Tarifvertragsrecht. Waxmann, Münster, 1988.

39 BAG v. 28.3.2006 ABR 58/04; BAG v. 05.10.2010 ABR 88/09.

40 KovÁcs (2008): i. m., 469, 474-476.

41 BAGDI Katalin: A Comparative Analysis of the Regulation of Works Agreements in Hungary and the EU Member States. In: P. Szabó Béla-Szemesi Sándor (szerk.): Profectus in litteris VI. Lícium-Art, Debrecen, 2015, 25-31. 
A probléma azonban inkább már az 1992-es Munka Törvénykönyvével felállított sajátos magyar dualista szerkezetü modellel van, amelyben gyakorlatilag az üzemi tanács vagy súlytalan, vagy szerepe összemosódik a szakszervezettel. ${ }^{42} \mathrm{Az}$ üzemi megállapodással - ahogy fentebb említettem - nem térhetnek el a díjazásra vonatkozó rendelkezésektöl, holott a bérmegállapodás tipikusan központi elem egy kollektív szerződésnél. Meg kell jegyezni azonban, hogy így is lehetőség nyílik a munkáltató szempontjából tipikusan kedvező rendelkezések elfogadására, például: elrendelhető éves rendkívüli munkaidő emelése, hosszabb munkaidőkeret, szigorúbb kártérítési szabályok, de a munkavállaló szempontjából is kedvezőbb lehet a díjazás kivételével az üzemi megállapodásban biztosított hosszabb végkielégítés, felmondási idő kikötése, törvényben biztosított szabadságon felüli szabadság, munkaidő-kedvezmények, béren kívüli juttatások beépítése és így tovább. E kedvezmények tárgyalása során kétség sem férhet hozzá, hogy az üzemi tanácsi tagok - a szakszervezeti képviselökhöz hasonló - érdekképviseleti tevékenységet folytatnak, ami ellentétes az üzemi tanács eredeti rendeltetésével, és megkérdőjelezhető az is, hogy az üzemi tanácsi választásokon erre kapott-e felhatalmazást. A legitimációs kérdéseket meghaladóan az üzemi tanács a szakszervezethez képest is kevésbé tud független maradni, hiszen valamennyi tagja a munkáltató munkavállalója, működési költségeit kizárólag a munkáltató finanszírozza. Ezzel szemben egy több munkáltatónál képviselettel rendelkező szakszervezet általában szervezeti függetlenséggel, továbbá bevételei - különösen az állami támogatások, felajánlások, tagdijak - révén erősebb pénzügyi és szakmai háttérrel rendelkezik. Gyakori, hogy a szakszervezetek szervezetén belül szakmai (pl. jogi) apparátus is müködik, illetőleg rendelkeznek külső jogi támogatással, az üzemi tanács azonban általában csak a megválasztott tagok (élet)tapasztalatára támaszkodhat. További körülmény, hogy az üzemi tanácsoknak nem állnak rendelkezésére a munkaharc eszközei sem, hiszen sztrájk esetén semleges, pártatlan magatartásra kötelesek. A sztrájk során az üzemi tanács mandátuma is felfüggesztésre kerül, és - szakszervezet hiányában - nincs olyan szervezetjellegű testület, amely hatékonyan tárgyalhatna a munkavállalói

${ }^{42} \mathrm{Az}$ üzemi tanács és a szakszervezet közötti funkcionális dilemma már a miniszteri indoklásban is tetten érhetö. A törvényjavaslat 11. pontja kifejezetten azt a szándékot fogalmazta meg, hogy a törvény ki kívánja zárni a konkurens érdekképviseleti tevékenységet a két szerv között: „A kollektív szerződés mellett a törvény lehetövé teszi, hogy az üzemi tanács (üzemi megbízott, központi üzemi tanács) és a munkáltató között létrejött ún. üzemi megállapodás is tartalmazzon munkaviszonyra vonatkozó szabályokat. Ezt a megoldást korábban - átmenetileg - a magyar munkajog már alkalmazta. E lehetőség ugyanakkor csak korlátozottan érvényesül annak érdekében, hogy a törvény kizárja a különböző munkavállalói érdekképviseletek konkurens tevékenységét."

Ezzel szemben mégis kiemeli az üzemi tanács szakszervezetet „pótló” szerepét, de facto hangsúlyozva ezzel, hogy érdekképviseleti feladatokat is elláthasson: „Az üzemi megállapodás e regulatív funkciójának törvényi szabályozása a hazai érdekképviseleti rendszernek azzal a sajátosságával is számol, hogy egyelöre a munkáltatók jelentős részénél nincs képviselettel rendelkező szakszervezet, illetve igen csekély számban jöttek létre ágazati (tágabb hatályú) kollektív szerződések. A törvény ugyanakkor kizárja a munkaviszonyra vonatkozó szabályok kollizióját azzal, hogy a munkaviszonyra vonatkozó szabály hatályú üzemi megállapodást csak abban az esetben engedi meg, ha a munkáltatóra nem terjed ki kollektív szerződés hatálya, illetve kollektív szerződés kötésére jogosult szakszervezet sincs. A törvény korlátozza az üzemi megállapodás tárgyi felhatalmazását is azzal, hogy a munka dijazására vonatkozó szabályok kialakitását e körben eltiltja." A munka törvénykönyvéről szóló T/4786. számú törvényjavaslat indoklása. Általános Indoklás, 11. 
érdekekért, és ezt - adott esetben - egy olyan tisztviselönek kell felvállalnia, aki nem rendelkezik a szakszervezeti tisztségviselőket egyébként megillető munkajogi védelemmel sem. Végső soron az üzemi megállapodással a kollektív szerződés békekötelmi jellege is kiüresedik, hiszen az üzemi tanács eleve semleges magatartásra köteles a sztrájkkal kapcsolatosan, holott a szakszervezet és a munkáltató közötti érdekvita sztrájk esetén általában az alku kollektív szerződésbe foglalásával zárul. ${ }^{43}$

Amennyiben a normatív üzemi megállapodás hatálya alatt egy olyan szakszervezet jelenik meg a munkáltatónál, amely eléri a kollektív szerződés kötéséhez szükséges taglétszámot, az üzemi megállapodás - bár csak hat hónap elteltével, de - hatályát veszti. ${ }^{44} \mathrm{~A}$ szakszervezet megjelenésével nemcsak egy esetleg addig tartósan kiegyensúlyozott foglalkoztatási feltételeket biztosító üzemi megállapodás veszítheti el jelentőségét, hanem az üzemi tanács is gyakorlatilag elveszíti az addig egyébként gyakorolt feladatát, és érdemi jogköre a klasszikus jogosítványaira korlátozódik.

\section{Következtetések}

A magyar munkajogban önmagában is kérdéses, mennyire sikerült az üzemi tanácsok helyét megtalálni. A kollektív szerződéskötési képességre vonatkozó új szabályokat is figyelembe véve, könnyen adódhat olyan helyzet, hogy egy szük kisebbség akarata érvényesül egy szakszervezet tevékenysége során, és a munkavállalók azt kevéssé érzik maguknak. Ehhez képest az üzemi tanács támogatottsága helyi szinten - az Mt.-ben szereplő részletes választási szabályokra hivatkozva - jobban mérhető, és ahhoz kevéssé férhet kétség. Ezenfelül az üzemi tanácsi tagot a munkavállalók közvetlenül és titkos szavazás útján maguk közül ${ }^{45}$ választják, továbbá a tagok visszahívhatók, ezáltal fölöttük bizonyos mértékig ellenőrzés gyakorolható, sőt amennyiben az üzemi tanács így nem éri el a törvényben meghatározott minimális létszámot, nemcsak az üzemi tanács megszünését eredményezi, hanem az üzemi megállapodás is hatályát veszti. A szakszervezet esetében csak a tagsága gyakorol kontrollt annak tevékenysége fölött, és a tízszázalékos munkavállalói kisebbség támogatásával az egész munkáltatóra kötelező hatályú normatív megállapodást fogadhat el anélkül, hogy vizsgálnák - a német Soziale Mächtigkeit-hoz hasonlóan - a szakszervezet taglétszámát, gazdasági erejét, függetlenségét,

43 KÁRTYÁs Gábor: Kollektív szerződés az üzemi tanáccsal, avagy a csizma az asztalon, http://www.hrblog.hu/ azujmt/2011/12/22/kollektiv-szerzodes-az-uzemi-tanaccsal-avagy-csizma-az-asztalon/ (2017. 06. 21.).

44 Az Mt. 268. § (3) bekezdése (3) A (2) bekezdés b) pontban, valamint a 252. § b)-g) pontban meghatározott esetben az üzemi megállapodás szabályait a megszủnéstől számított hat hónapig alkalmazni kell.

45 Ez azért is fontos körülmény, mert feltételezhetjük, hogy a választók személyesen is ismerik azt a személyt, akit megválasztanak, alátámasztva ezzel a megválasztott tag legitimációját. Megerősíti a közvetlenséget a passzív választójogra vonatkozó rendelkezések, azaz üzemi tanácstaggá az a cselekvőképes munkavállaló választható, aki legalább hat hónapja a munkáltatóval munkaviszonyban áll és az adott telephelyen dolgozik. Nehezen állhat elő olyan helyzet tehát, hogy a telephelyen valójában nem dolgozó, illetőleg az üzemi viszonyokat nem ismerő és a munkavállalók körében is ismeretlen személy legyen üzemi tanács tagja. Ezzel szemben a szakszervezeti képviselővel gyakran személyes kapcsolatuk sincs a munkavállalóknak. 
és végső soron a támogatottságát, különösen üzemi szinten, vagy hogy biztosítva legyen, hogy helyi szinten a nem tag munkavállalók a szakszervezeti tisztségviselőt elmozdíthassák, tevékenysége fölött másfajta ellenőrzést gyakorolhassanak. A munkavállaló, valamint a támogatását bíró üzemi tanács joggal tarthat attól, hogy az üzemi megállapodásban megerősített és kivívott jogosultságok veszélybe kerülnek egy szakszervezet megjelenésével, ami bizalmatlanságot eredményezhet. Azok a munkavállalók, akiknek érdekeit egy üzemi tanács is hatékonyan tudja képviselni és érvényre juttatni egy üzemi megállapodás útján, maguk sem válnak érdekeltté abban, hogy egy olyan szakszervezet vegye át ezeket a feladatokat, amely fölött - a szabályozásból eredően is - kevesebb kontrollt tudnak gyakorolni, aminek a müködéséhez tagság esetén tagdíj formájában is hozzá kellene járulni. Ezáltal sem a munkavállalók, sem az üzemi tanács nem lesznek érdekeltek abban, hogy a szakszervezet tevékenységét támogassák, és ez a szembefordulás gyakorlatilag nem másból, mint a szabályozásból ered. ${ }^{46}$ Más kérdés, hogy a hatásköri összemosódások az új törvénnyel megvalósult elkülönítési törekvések ellenére azzal párosulnak, hogy a szakszervezeteknek jelentős befolyása van az üzemi tanácsokban, és az üzemi tanács tagjai egyben szakszervezeti tisztségviselők is, sőt bizonyos esetekben - kollektív szerződés felhatalmazása alapján - a szakszervezet gyakorolja az üzemi tanácsi feladatokat is. ${ }^{47}$

Azt a körülményt is érdemes megemlíteni, hogy Magyarországon a szakszervezeti szervezettség mértéke folyamatosan csökken, továbbá uniós és világviszonylatban is alacsony. ${ }^{48}$ A legfrisseb KSH-felmérések alapján hazánkban a szakszervezeti és az üzemi tanácsi jelenlét (szervezettség) között nincs jelentős különbség, továbbá tipikusan azokban az ágazatokban magasabb az üzemi tanács jelenléte, ahol a szakszervezeteké is. ${ }^{49} \mathrm{Ha}$ nem lenne lehetőség normatív tartalmú üzemi

46 „Várható, hogy a munkáltatók többségénél nem lesz kollektív szerződés-kötésre jogosult szakszervezet. Ennek fényében az 1992-es törvény sokkal őszintébben támogatta a kollektív autonómia érvényesülését az üzemi tanácsi választási eredményekhez kötött (és Európában távolról sem egyedülálló) kollektív szerződéskötési joggal. Különös figyelemmel arra is, hogy az erga omnes hatályú kollektív szerződések megkötésére így a munkavállalók többségének bizalmát élvező szakszervezetek váltak jogosulttá. Ennek fényében a szakszervezeti kollektív szerződéskötési jogosultságot a munkahelyi jelenlét tíz százalékához kötni (mindenféle alternatív megoldás kizárásával, sőt megtiltásával, hiszen az Mt. megtiltja a kollektív szerződésre vonatkozó normáktól való eltérést) és egyidejüleg a »kollektív autonómia kiterjesztéséről« beszélni finoman szólva is önellentmondás." Lásd LeHOCZKYNÉ KolLonAY Csilla: Génmanipulált újszülött - Új munkatörvény az autoriter és neoliberális munkajogi rendszerek határán. In: Kun Attila (szerk.): Az új munka törvénykönyve dilemmái című tudományos konferencia utókiadványa. Károli Gáspár Református Egyetem Állam- és Jogtudományi Kar, Budapest, 2013, 24-56.

47 Neumann László: A szakszervezet jogállásának változása, kollektív alku, béralku, bércsökkenés. In: Laki Mihály-Nacsa Beáta-Neumann László: Az új Munka Törvénykönyvének hatása a munkavállalók és a munkáltatók közötti kapcsolatokra. Kutatási zárójelentés. Műhelytanulmányok MT-DP - 2013/2 Magyar Tudományos Akadémia Közgazdaság- és Regionális Tudományi Kutatóközpont, Közgazdaság-tudományi Intézet, Budapest, 2013, 25, http://mek.oszk.hu/11400/11439/11439.pdf (2018. 07. 13.).

48 Szabó Imre Szilárd blogbejegyzésében részletesen elemzi a csökkenő szakszervezeti taglétszámot és a kollektív szerződéses lefedettséget a KSH 2016-ban megjelent kimutatásai alapján, http://szabim.blog. hu/2016/05/17/_hianypotlo_adatokat_kozolt_a_kozponti_statisztikai_hivatal (2018. 03.31.).

49 A felmérés eredménye alapján a munkáltatók $25,1 \%$-ánál működik valamilyen szakszervezet, és $17,9 \%$-ánál müködik üzemi tanács. A szakszervezetekre vonatkozóan: https://www.ksh.hu/docs/hun/xstadat/xstadat_ 
megállapodás megkötésére, vagy annak szabályozási lehetőségeit a jogszabály jelentősen korlátozná a kollektív szerződéshez képest, mind a munkáltató, mind a szakszervezetek útján képviselt valamennyi munkavállaló érdekeltté válna abban, hogy a rugalmasabb, több szabályozási lehetőséget biztosító kollektív szerződést válasszák. A jelenlegi szabályokkal adott esetben a munkáltató az üzemi tanács útján is elérheti azokat a számára kedvezőbb foglalkoztatási feltételeket, amelyeket egy kollektív tárgyalásban jártasabb, többéves tapasztalattal rendelkező, esetlegesen szakmai támogatással, vagyonnal bíró szakszervezettel szemben, más erőviszonyok mentén nem biztos, hogy sikerrel tudna egy megállapodásban rögzíteni. Minél több lehetősége van egy munkáltatónak a szakszervezettel való konfrontáció elkerülésére, annál inkább válik a kollektív autonómia, végső soron a kollektív tárgyalás is kiüresedett intézménnyé. Amennyiben azonban egy szakszervezet kollektív szerződéskötési képességet szerez a munkáltatónál, az üzemi tanács veszíti el gyakorlati jelentőségét, és az egy mellékes, csupán konzultatív szereplővé minősül vissza. ${ }^{50}$ Tovább gyengíti az üzemi tanács pozícióját, hogy a konzultációs, illetve tájékoztatási védelme érdekében gyakorlatilag semmilyen kényszerítőeszköz sem áll rendelkezésére, csupán az Mt. 289. § szerint, nemperes eljárás keretében jogsértés megállapítására kerülhet sor, vagy esetlegesen egyeztetés vagy döntőbíráskodás keretében rendezhetik a kérdést.

Általánosságban véve az a jogalkotói cél, hogy szélesebb körü kollektív autonómiát biztosítson a szerződést kötő feleknek, a szakszervezetek tekintetében akadályba ütközhet az érdekérvényesítési funkciók összemosódása miatt. Kollektív szerződéskötési képességgel rendelkező szakszervezet hiányában a normatív üzemi megállapodás tekintetében az üzemi tanács - különösen annak megtárgyalása, megkötése során - érdekképviseleti funkciókat gyakorol, ami egyrészről alkupozíció vesztését is eredményezheti a munkáltatóval szemben egy szakszervezet megjelenése esetén, ${ }^{51}$ másrészröl többirányú legitimációs konfliktus is azonosítható, hiszen a szakszervezet korántsem biztos, hogy bírja a többség támogatását, de az sem kézenfekvő, hogy a munkavállalók az alapvetően participációs jogokat gyakorló üzemi tanácsot arra hatalmazzák fel, hogy szakszervezeti jogosultságokat gyakoroljon és kollektív szerződést kössön. Függetlenül ezért attól, hogy milyen mértékben jelentős a normatív üzemi megállapodás a gyakorlatban, álláspontom szerint érdemes volna élesebb határvonalat húzni a szakszervezet és az üzemi tanács funkciói, valamint a kollektív szerződés és az üzemi megállapodás tartalmát illetően, a fentebb felvázolt

evkozi/e_szerv9_01_15.html (2018. 07. 13.) az üzemi tanácsokra vonatkozóan: https://www.ksh.hu/docs/ hun/xstadat/xstadat_evkozi/e_szerv9_01_36.html (2018.07.13.).

50 Több magyar munkajogász fejtette ki azon álláspontját, hogy az üzemi tanácsok létezése a jelenlegi formában szükségtelen. Lásd GYulAváRı Tamás: „Út a rugalmasságba”. In: Kun Attila (szerk.): Az új munka törvénykönyve dilemmái címü tudományos konferencia utókiadványa. Károli Gáspár Református Egyetem Állam- és Jogtudományi Kar, Budapest, 2013, 102; HoRvÁTH István: Fényárnyék. Húsz percben az új Munka Törvénykönyvéröl. In: Kun Attila (szerk.): Az új munka törvénykönyve dilemmái címü tudományos konferencia utókiadványa. Károli Gáspár Református Egyetem Állam- és Jogtudományi Kar, Budapest, 2013, 87-88.

51 Ha a szakszervezet nem hajlandó megkötni a munkáltatóval a rá nézve előnyösebb kollektív szerződést, akkor azon lesz, hogy megegyezzen az üzemi tanáccsal, emellett a szakszervezet tevékenységét ne támogassa stb. 
anomáliák elkerülése végett, vagy pedig az üzemi szintű érdekképviseletet egyedül az üzemi tanácsokra (vagy a szakszervezetekre) bízni, elkerülve ezzel a párhuzamos funkciókból eredő összeütközést. ${ }^{52}$

\begin{abstract}
The study focuses on the separation of two classical institutions of collective labour law: the labour unions and the works councils. Traditionally, labour unions are associations intended to represent and protect the collective interests of workers; works councils are units that exercise the workers' participation rights, and are mechanisms where the employees can influence the decisions of the employer at the workplace. The distribution of traditional union and works council authorities, however, is not that obvious, especially from a practical point of view. The study strives to highlight those areas where the unions and the works councils appear as opposing parties, especially focusing on works agreements with normative power, from a practical and an international comparative perspective, and to offer solutions de lege ferenda.
\end{abstract}

52 A funkciók összemosódásával kapcsolatos problémák a lengyel üzemi tanácsi rendszert is érintik egyébként. Katarzyna Skorupińska legföbb problémaként jelöli meg a gyenge üzemi tanácsi jogositványokat, jogi és gazdasági tapasztalat hiányát az üzemi tanácsi tagoknál, a szakszervezeti összefonódásokat és az ebből fakadó funkcionális félreértéseket a munkavállalók részéröl, továbbá a bizalom hiányát a munkáltató részéröl. Lásd bővebben: SKORUPIŃSKA, Katarzyna: The failure of a new form of employee representation: Polish works councils in comparative perspective. European Journal of Industrial Relations, Vol. 24 No. 2, 163-178; továbbá http://users.unimi.it/ileraeurope2016/wp-content/uploads/gravity_forms/1-0bf0a63ff09 eb6c2235a1ac64e151639/2016/08/Skorupinska_ILERA.pdf (2018. 07. 13.). A lengyel párhuzam abból a szempontból is érdekes, hogy a kollektív szerződéskötési képességhez szükséges 10 százalékos viszonyszám szintén lengyel mintára került bevezetésre Magyarországon. SzABó (2017): i. m. 